\title{
Penegakan Hukum dalam Pengungkapan Kasus Tindak Pidana Aborsi di Kota Ternate
}

\author{
Faisal
}

Fakultas Hukum Universitas Khairun. E-mail: faisaldjabid5@gmail.com

\author{
Muhaimin Limatahu \\ Fakultas Hukum Universitas Khairun.E-mail: muhaimin.limatahu@gmail.com
}

\begin{abstract}
:
The rise of the practice of abortion at this time seemed to be a social phenomenon that is difficult to solve. From year to year the number of people who practice abortion is increasing and of course this is a reflection for all parties to be able to find the best solution in solving abortion cases. Lack of community and adolescent awareness, in understanding the impact of these abortions on health and lives, as well as legal threats for abortionists, lack of parental supervision in supervising children, no hospital reports for patients who have committed post-abortion crimes. It is hoped that the police can increase the professionalism of investigators in handling and disclosing cases of abortion in Ternate, as well as police investigators not just waiting for reports, but can collaborate between police investigators and hospitals, maternity clinics and obstetric practice places, in order to obtain information and data on cases related to post-criminal abortion crimes, as well as efforts to prevent abortion from perpetrated by hospitals and maternity clinics and midwifery practices.
\end{abstract}

Keywords: Law Enforcement, Criminal Acts, Abortion.

\section{PENDAHULUAN}

Sistem hukum di Indonesia, perbuatan aborsi dikategorikan perbuatan pidana, sehinga kepada pelaku dan orang yang membantu melakukan di kenai hukuman. Walaupun sebagian masyarakat Indonesia sudah menetahui ketentuan tersebut, masih banyak juga perempuan yang melakukan aborsi. di era melenial ini membuat nilai-nilai moral yang ada dalam masyarakat menjadi semakin berkurang. Informasi konten negative yang berbau pornografi semakin meluas, Pergaulan menjadi semakin bebas sehingga melanggar batas-batas nilai moral, prilaku serta agama dalam kehidupan masyarakat di Kota Ternate. Hubungan seks yang seharusnya hanya boleh dilakukan dalam ikatan perkawinan sudah dianggap wajar dalam status pacaran.

Pengguguran janin atau lebih sering disebut istilah aborsi merupakan fenomena sosial yang semakin hari semakin memprihatinkan. Keprihatinan ini bukan tanpa alasan, karena sejauh ini perilaku aborsi banyak menimbulkan efek negatif baik terhadap diri sendiri maupun masyarakat. Hakikat kehidupan merupakan suatu anugera yang diberikan oleh Tuhan Yang Maha Esa yang harus dihormati oleh setiap orang. Kehidupan yang diberikan kepada setiap manusia merupakan hak asasi manusia yang hanya boleh dicabut oleh pemberi kehidupan tersebut. Hak untuk hidup adalah salah satu hak asasi manusia yang dicantumkan dalam konstitusi sebagaimana dijelaskan dalam pasal 28 (a) Undang-Undang Dasar 1945 yang berbunyi "setiap orang berhak untuk hidup serta berhak mempertahankan hidup dan kehidupannya". Dengan hak hidup itu Negara akan menjaga dan melindungi hak hidup setiap 
warganya , sehingga negara melalui alat negara penegak hukum akan bertindak apabila ada dan diketahui terjadi penghilangan hak hidup manusia. ${ }^{1}$

Praktek Aborsi sudah bukan rahasia lagi, terutama dengan semakin meluasnya budaya pergaulan bebas dikalangan masyarakat, remaja dan maraknya prostitusi dewasa ini. Hal tersebut pada gilirannya mendorong orang-orang tertentu yang cenderung menggugurkan kandungan dengan melakukan aborsi ilegal sebagai solusi untuk menghilangkan aib. Maraknya Praktek Aborsi pada saat ini seakan menjadi fenomena sosial yang sulit terpecahkan. Dari tahun ke tahun jumlah orang yang melakukan praktek Aborsi semakin bertambah dan tentunya ini menjadi cerminan untuk semua pihak agar dapat mencari solusi yang terbaik di dalam penyelesaian kasus aborsi tersebut.

Kehamilan di luar nikah memiliki kolerasi dengan kasus aborsi, artinya aborsi itu dilakukan karena kondisi kehamilan yang diproduk melalui kegiatan pergaulan bebas. Baik yang bermodus promiskuitas (hubungan seks dengan berganti-ganti pasangan) maupun karena kumpul kebo (semenleven). Hal demikian semakin meresahkan masyarakat, terutama keluarga mereka yang memiliki anak gadis remaja yang belum nikah.

Data prapenelitian yang peneliti temukan di RS. Chasan Bosoerie Ternate di bagian Ginekologi menurut keterangan dari Ibu Kartini Kalbamay, Kepala Ruangan Ginekologi, bahwa data aborsi dari tahun 2015 hingga 2018 terdapat 27 (dua puluh tujuh) tindakan abortus provokatus kriminalis yang telah ditangani pihak rumah sakit. 27 pelaku tindakan aborsi itu, dilakukan oleh dukun beranak, dan juga pelaku mengunakan, obat-obatan, jamu, dan kayu, yang dapat menggugurkan kandungan. Dari 27 pelaku tindak pidana aborsi semuanya beralamat di Kota Ternate. ${ }^{2}$

Perilaku aborsi yang akhir-akhir ini banyak terkuak menyebabkan masaalah ini menarik untuk diangkat mengingat bahwa tidak semua remaja putri maupun wanita yang sudah menikah memiliki pengetahuan tentang aborsi. Dalam kenyataannya, usia aborsi secara spesifik sulit didapatkan karena aborsi yang dilakukan remaja putri maupun hasil dari perselingkuhan wanita yang sudah menikah karena tidak ada pertangungjawaban dari laki-laki tersebut, sehingga umumnya mereka sering melakukan tindakan aborsi illegal yang dilrang oleh pemerintah dan dilakukan dengan cara-cara tidak aman misalnya dengan meminta bantuan dukun beranak, minum ramuan peluntur, dan lain-lain. Oleh karena itu aborsi yang dilakukan sering kali mengancam keselamatan wanita yang melakukan aborsi. Hal tersebut menyebabkan tingginya angka kematian wanita akibat aborsi.

\section{KAJIAN KEPUSTAKAAN}

\section{A. Pengertian Penegakan Hukum}

Penegakan hukum merupakan usaha untuk mewujudkan ide-ide dan konsep-konsep hukum yang diharapakan rakyat menjadi kenyataan. Penegakan hukum merupakan suatu proses yang melibatkan banyak hal. Menurut Soerjono Soekanto, penegakan hukum adalah kegiatan menyerasikan hubungan nilai-nilai yang terjabarkan didalam kaidah-kaidah/pandangan nilai yang mantap dan mengejewantah dan sikap tindak sebagai rangkaian penjabaran nilai tahap akhir untuk menciptakan, memelihara dan mempertahankan kedamaian pergaulan hidup. ${ }^{3}$

Pengetahuan dan pengertian penyidikan perlu dinyatakan dengan pasti dan jelas, karena hal itu langsung menyinggung dan membatasi hak-hak asasi manusia. Bagian-bagian hukum

1 Masrudi Muchtar, Etika Profesi Hukum Kesehatan Perspektif Profesi Bidan Dalam Pelayanan Kebidanan Di Indonesia. Yogyakarta Pustaka Baru Press. 2016 hlm 163.

2 Wawancara Prapenelitian Kartini Kalbamay, Kepala Ruangan Ginekologi RS. Chasan Bosoerie Ternate, Tanggal 5 Maret 2019.

${ }^{3}$ http://digilib.unila.ac.id/2827/12/BAB\%20II.pdf. Di Kutip Dellyana,Shant.1988,Konsep Penegakan Hukum. Yogyakarta: Liberty hal 32 
acara pidana yang menyangkut penyidikan adalah sebagai berikut:

1) Ketentuan tentang alat-alat bukti.

2) Ketentuan tentang diketahui terjadinya delik.

3) Pemeriksaan di tempat kejadian.

4) Pemanggilan tersangka atau terdakwa.

5) Penahanan sementara.

6) Penggeledahan.

7) Pemeriksaan atau interogasi.

8) Berita acara (penggeledahan, interogasi, dan pemeriksaan di tempat).

9) penyitaan.

10) Penyampaian perkara.

\section{B. Tugas dan Wewenang Kepolisian}

Berdasarkan Pasal 13 Undang-undang Nomor 2 Tahun 2002 Tentang Kepolisian Negara Republik Indonesia, Tugas pokok Kepolisian Negara Republik Indonesia adalah: ${ }^{4}$

a. memelihara keamanan dan ketertiban masyarakat;

b. menegakkan hukum; dan

c. memberikan perlindungan, pengayoman, dan pelayanan kepada masyarakat.

Di dalam menjalankan peranannya dalam memelihara keamanan dan ketertiban masyarakat, menegakkan hukum, memberikan pengayoman dan pelayanan kepada masyarakat, Kepolisian Negara republik Indonesia wajib memiliki keahlian dan keterampilan secara profesional.

Selain apa yang diatur di dalam Pasal 7 KUHAP, juga Pasal 8 KUHAP mengatur tentang kewenangan dan tata cara penyidik menyerahkan berkas perkara kepada penuntut umum, penyerahan perkara itu meliputi dua tahap yaitu: pertama penyidik hanya menyerahkan berkas perkara dan kedua dalam hal penyidikan sudah dianggap selesai, penyidik menyerahkan tanggung jawab atas tersangka dan barang bukti kepada penuntut umum. ${ }^{5}$

\section{Pengertian Aborsi Secara Umum}

Di lain pihak istilah aborsi menurut dr. Agus Abadi dari Lab Ilmu Kebidanan dan Penyakit Kandungan RSUD Dr. Soetomo, abortus (definisi yang lama) adalah terhentinya kehidupan buah kehamilan pada usia kehamilan sebelum 20 minggu atau berat janin kurang dari 500 gram. WHO memperbaharui definisi aborsi yakni aborsi adalah terhentinya kehidupan buah kehamilan di bawah 28 minggu atau berat janin kurang dari 1000 gram. Aborsi juga diartikan mengeluarkaan atau membuang baik embrio atau fetus secara prematur (sebelum waktunya). Istilah aborsi disebut juga abortus provokatus (inilah yang belakangan ini menjadi ramai dibicarakan). Abortus yang dilakukan secara sengaja. Jadi Aborsi adalah tindakan pengguguran hasil konsepsi secara sengaja. ${ }^{6}$

Menurut kamus bahasa Indonesia, aborsi adalah terpencarnya embrio yang tidak mungkin lagi hidup sebelum habis bulan keempat dari kehamilan atau aborsi bisa didefinisikan pengguguran janin embrio setelah melebihi masa dua bulan kehamilan. Menurut perspektif medis aborsi adalah penghentian kehamilan setelah tertanamnya telur (ovum) yang telah

\footnotetext{
4 Undang-undang Kepolisian Negara Repoblik Indonesia, Fokusmedia. Bandung, 2012.

${ }^{5}$ Djisman Samosir, Segenggam Tentang Hukum Acara Pidana, Penerbit Nusa Aulia, 2013, hlm. 39.

${ }^{6} \mathrm{http} / / /$ sonny-tobelo.blogspot.co.id/2009/02/peranan-polri-dalam-penyidikan-tindak.html
} 
dibuahi dalam rahim (uterus) sebelum usia janin (fetus) mencapai 20 minggu. $^{7}$

Aborsi terinduksi (yang disengaja), terjadi akibat campur tangan yang besifat medis, bedah, atau akibat penggunaan sediaan herba atau praktik tradisional lain yang menyebabkan uterus mengeluarkan isinya atau mengeluarkan sebagian isinya. Aborsi yang disengaja dapat bersifat legal atau illegal menurut hukum Negara. ${ }^{8}$

Aborsi legal, dilakukan oleh praktisi medis yang disetujui oleh hukum di suatu Negara, yang menggugurkan kehamilan karena alsan yang diijinkan oleh hukum. Juga terdapat syarat-syarat yang harus dipenuhi, yaitu prosedur tersebut dilakukan dengan cara yang disetujui, dan di bidan harus mengetahui di Negara mereka yang berkenaan dengan aborsi. Di beberapa Negara, aborsi dianggap legal apa pun alasan dan situasinya tempat atau institusi yang disetujui.

Aborsi ilegal, setiap aborsi yang dilakukan oleh orang yang tidak diizinkan oleh hukum Negara yang relevan untuk menjalankan prosedur tersebut. Terdapat risiko sepsis dan/ atau hemoragi serta cedera yang sangat tinggi. Didalam undang-undang nomor 36 tahun 2009 tentang kesehatan, kesehatan reproduksi memperoleh perhatian khusus. Hal ini wajar bahwa masalah kesehatan reproduksi di Negara-negara berkembang termasuk Indonesia menjadi masalah kesehatan yang utama. Akibat rendahnya kesehatan reproduksi, terutama pada wanita, maka akan berdampak terhadap tingginya angka kematian bayi dan kematian ibu karena melahirkan. Padahal kedua indikator tersebut merupakan bagian terpenting dalam pencapaian tujuan pembangunan millennium. ${ }^{9}$

Abortus kriminal dapat dilakukan oleh wanita itu sendiri atau dengan bantuan orang lain (dokter, bidan, perawat, dukun beranak dan lain-lain). Tindakan ini biasanya dilakukan sejak yang bersangkutan terlambat datang bulan dan curiga akibat hamil. Biasanya kecurigaan ini datang pada minggu ke-5 sampai minggu ke-10. Pada waktu ini mungkin disertai gejala mual pagi hari (morning sickness). Sekarang kecurigaan adanya kehamilan dapat diketahui lebih dini karena sudah ada alat tes kehamilan yang dapat mendiagnosa kehamilan secara pasti. ${ }^{10}$

Tujuan pemakaian berbagai macam jamu dan obat adalah memberi peredaran darah yang berlebihan di perut bagian bawah, hiperemia, sehingga rahim menjadi peka dan mudah berkontraksi atau membuat perut merasa mulas, kejang dan rahim ikut berkontraksi. Dalam masyarakat pengguna obat tradisional seperti nenas muda, jamu peluntur dan lain-lain sudah lama dikenal. Melalui iklan promosi obat di media elektronik beberapa obat peluntur ditawarkan secara terselubung, misalnya obat terlambat datang bulan; dilarang untuk wanita hamil dan lain-lain.

Hal mana dapat disebabkan karena adanya kelainan dari mudigah atau fetus maupun adanya penyakit pada ibu.

a. Abortus yang terjadi akibat kecelakaan.

Seorang ibu yang sedang hamil bila mengalami rudapaksa, khususnya rudapaksa di daerah perut, akan dapat mengalami abortus; yang biasanya disertai dengan perdarahan yang hebat. Kecelakaan yang dapat terjadi karena si ibu terpukul, shock atau rudapaksa lain pada daerah perut, hal mana biasanya jarang terjadi kecuali bila si-ibu mendapat luka yang berat.

7 Masrudi Muchtar, Etika Profesi Hukum Kesehatan Perspektif Profesi Bidan Dalam Pelayanan Kebidanan Di Indonesia. Yogyakarta Pustaka Baru Press. 2016. Ibid hal 192-193

${ }^{8}$ Estu tiar. Edisi 2 Modul Kebidanan Manajemen Aborsi Inkomplet. Penerbit Buku Kedokteran EGC. Jakarta, 2009. hlm 29.

9 Masrudi Muchtar, Etika Profesi Hukum Kesehatan Perspektif Profesi Bidan Dalam Pelayanan Kebidanan Di Indonesia. Yogyakarta Pustaka Baru Press. 2016. Ibid hal 156-158

${ }^{10} \mathrm{https} / / /$ ningrumwahyuni.wordpress.com/2009/11/22/abortus-dalam-kaitannya-dengan-ilmukedokteran-forensik-dan-medikolegal. 
b. Abortus provocatus medicinalis atau abortus theurapeticus.

Yaitu penghentian kehamilan dengan tujuan agar kesehatan si-ibu baik agar nyawanya dapat diselamatkan. Abortus yang dilakukan atas dasar pengobatan (indikasi medis), biasanya baru dikerjakan bila kehamilan mengganggu kesehatan atau membahayakan nyawa si ibu, misalnya bila si ibu menderita kanker atau penyakit lain yang akan mendatangkan bahaya maut bila kehamilan tidak dihentikan.

c. Abortus provocatus criminalis atau abortus kriminalis.

Yaitu tindakan abortus yang tidak mempunyai alasan medis yang dapat dipertanggungjawabkan atau tanpa mempunyai arti medis yang bermakna. Jelas tindakan penguguran kandungan di sini semata-mata untuk tujuan yang tidak baik dan melawan hukum. Tindakan abortus tidak bisa dipertanggungjawabkan secara medis, dan dilakukan hanya untuk kepentingan si pelaku, walaupun ada kepentingan juga dari si ibu yang malu akan kehamilannya. Kejahatan jenis ini sulit untuk melacaknya oleh karena kedua belah pihak menginginkan agar abortus dapat terlaksana dengan baik (crime without victim, walaupun sebenarnya korbannya ada yaitu bayi yang dikandung).

\section{Aborsi Dalam Penangganan Kedokteran.}

Di kalangan ahli kedokteran dikenal dua macam abortus (keguguran kandungan) yakni abortus spontan dan abortus buatan. Abortus spontan adalah merupakan mekanisme alamiah yang menyebabkan terhentinya proses kehamilan sebelum berumur 28 minggu. Penyebabnya dapat oleh karena penyakit yang diderita si ibu ataupun sebab-sebab lain yang pada umumnya berhubungan dengan kelainan pada sistem reproduksi. Lain halnya dengan abortus buatan, abortus dengan jenis ini merupakan suatu upaya yang disengaja untuk menghentikan proses kehamilan sebelum berumur 28 minggu, dimana janin (hasil konsepsi) yang dikeluarkan tidak bisa bertahan hidup di dunia luar. ${ }^{11}$

Menurut gambaran klinis, Aborsi dibedakan atas:

a. Abortus membakat (imminens) yaitu abortus tingkat permulaan, dimana terjadi perdarahan pervaginam, ostium uteri masih tertutup dan hasil konsepsi masih baik dalam kandungan.

b. Abortus insipiens yaitu abortus yang sedang mengancam dimana serviks telah mendatar dan ostium uteri telah membuka, akan tetapi hasil konsepsi masih dalam kavum uteri.

c. Abortus inkomplit yaitu jika hanya sebagian hasil konsepsi yang dikeluarkan, yang tertinggal adalah desidua atau plasenta.

d. Abortus komplit artinya seluruh hasil konsepsi telah keluar (desidua atau fetus), sehingga rongga rahim kosong.

e. Missed abortion adalah abortus dimana fetus atau embrio telah meninggal dalam kandungan sebelum kehamilan 20 minggu, akan tetapi hasil konsepsi seluruhnya masih tertahan dalam kandungan selama 6 minggu atau lebih.

f. Abortus habitualis (keguguran berulang) adalah keadaan terjadinya abortus tiga kali berturut-turut atau lebih.

g. Abortus infeksiosa adalah abortus yang disertai infeksi genital.

h. Abortus septik adalah abortus yang disertai infeksi berat dengan penyebaran kuman ataupun toksinnya kedalam peredaran darah atau peritonium.

Didalam ilmu kedokteran, istilah-istilah ini digunakan untuk membedakan aborsi:

a. Spontaneous abortion: gugur kandungan yang disebabkan oleh trauma kecelakaan atau sebab-sebab alami.

11 https://www.kompasiana.com/janewinarni/pengambilan-keputusan-etis-tentang-kasus-abortusdalam-medis-hukum-dan-agama. ungga tanggal 24 Agustus 2017. 
de Jure; Jurnal Ilmiah Ilmu Hukum $\bigcirc$ Vol. 1 No. 1 Desember (2019) : 1-15

b. Induced abortion atau procured abortion: pengguguran kandungan yang disengaja. Termasuk di dalamnya adalah:

1) Therapeutic abortion: pengguguran yang dilakukan karena kehamilan tersebut mengancam kesehatan jasmani atau rohani sang ibu, kadang-kadang dilakukan sesudah pemerkosaan.

2) Eugenic abortion: pengguguran yang dilakukan terhadap janin yang cacat.

3) Elective abortion: pengguguran yang dilakukan untuk alasan-alasan lain.

\section{E. Motif Pelaku Melakukan Tindakan Aborsi.}

Usia remaja usia yang sangat rentan, usia yang sangat gegabah, usia yang masih labil, usia yang belum bisa menentukan keputusan yang baik berdasarkan rasio maupun logia yang berdasarkan sesuatu yang sifatnya positif. Remaja yang diamati ini merupakan remaja yang sifatnya mencoba-coba, yang tidak memikirkan resiko yang akan terjadi. Berangkat dari kebebasan yang memeberikan kesempatan buat mereka untuk bertindak diluar kendali. Karena jauh dari pantauan keamanan, tidak ada ibu/bapak kost, kontrakan yang bebas tidak ada aturan, tidak ada system dari warga sekitar. Dari hal itu mereka akan bebas bebuat hal semau mereka.

Hasrat yang didasarkan cinta itu yang menggiring mereka untuk berbuat diluar kendali yaitu berhubungan intim yang tentunya stausnya bukan suami istri tetapi masih status pacaran. Tidak disadari perbuatan mereka memberikan masalah baru buat hubungan mereka yaitu hamil diluar nikah. Reaksi spontan mereka adalah aborsi jalan terbaik buat mereka, mereka berpikir dengan aborsi mereka tidak akan ketahuan kalau mereka hamil, tidak siap menghadapi apa yang akan terjadi, yaitu berhenti kuliah, cuti kuliah, kena mara terutama orang tua, malu dengan lingkungan maupun tetangga sekitar, cemohan dari teman-teman kampus.

Spontanitas aborsi yang dilakukan mereka adalah merupakan sebagai inti dari kepribadian mereka. Ada hasyrat diri mereka yang menggerakan untuk berbuat demikian. Jika keakuan dari mereka pada disposisi negatif mereka tidak akan berbuat aborsi karean mereka menolak bahwa perbuatan aborsi merupakan perbuatan beresiko dari segala sudut pandangan. Dari medis hal itu akan merusak kesehatan, dari pandangan etika sosial, maupun agama hal itu sangat dilarang dan diharamkan.

\section{METODE PENELITIAN}

Berdasarkan rumusan masalah dan tujuan yang ingin dicapai dalam penelitian ini yakni kajian hukum Kesehatan maka jenis penelitian yang digunakan adalah penelitian normative-empiris, dengan melakukan pencegahan dan penindakan dengan melihat berbagai norma hukum yang sudah ada/yang dikehendaki, bukan semata mempelajari norma hukum yang berlaku, tetapi juga melihat dari berbagai problem yang terjadi dengan berbagai pendekatan yang ada. Dengan demikian maka pemerintah Kota Ternate beserta Kepolisian Resort Ternate berusaha melakukan suatu tindakan pencegahan maupun penindakan sehingga pemerintah Kota Ternate dapat mengharapkan, tidak lagi terjadi tindakan aborsi Kriminal oleh masyarakat maupun remaja di Kota Ternate.

Pendekatan yang digunakan dalam penelitian ini, yaitu pendekatan perundang-undangan, dan berbagai kebijakan yang di buat. Dalam konteks ini, ketentuan-ketentuan yang akan ditelaah dan dikaji adalah beberapa instrumen hukum nasional dan kebijakan daerah, ${ }^{12}$ sedangkan untuk menganalisis penulis menggunakan pendekatan konseptual (conceptual approach) dan pendekatan kasus (case approach), (Peter Mahmud Marzuki, 2010:137).

\footnotetext{
${ }^{12}$ Peter Mahmud Marzuki, Penelitian Hukum, ( Jakarta, Kencana., 2007)., hlm.96.
} 
Data yang hendak dipergunakan dalam penelitian ini, dikategorikan ke dalam data sekunder yang diperoleh melalui bahan-bahan pustaka, yang mencakup (Soerjono Soekanto dan Sri Mamudji, 2011:14): ${ }^{13}$

1. Bahan hukum primer, yaitu bahan-bahan hukum yang mengikat dan terdiri dari norma dasar, peraturan dasar, peraturan perundang-undangan, dan bahan hukum yang relevan.

2. Bahan hukum sekunder, yang memberikan penjelasan mengenai bahan hukum primer seperti rancangan undang-undang, hasil-hasil penelitian, dan jurnal ilmiah.

3. Bahan hukum tertier, yakni bahan yang memberikan petunjuk dan penjelasan terhadap bahan hukum primer dan sekunder, seperti kamus dan ensiklopedia.

Teknik pengumpulan data yang dipergunakan adalah studi dokumen atau bahan kepustakaan yaitu penelusuran terhadap dokumen resmi dan tidak resmi sebagai bahan hukum primer dan sekunder untuk memperoleh data sekunder yang relevan yang kemudian akan dijadikan bahan acuan dalam menganalisis permasalahan yang ada. Selain itu, wawancara terstruktur juga dilakukan kepada pihak-pihak yang berkepentingan guna mendapatkan data secara komprehensif.

\section{PEMBAHASAN}

\section{A. Motif Pelaku Melakukan Tindak Pidana Aborsi Di Kota Ternate.}

Sebagaimana penulis telah menjelaskan pada bab sebelumnya, bahwa tindakan aborsi, merupakan perbuatan yang tercela dan dikategorikan sebagai kejahatan yang diatur dan diancam pidana bagi orang yang melakukannya, oleh karena itu para pelaku aborsi selalu berusaha untuk tidak diketahui oleh orang lain, terutama pihak kepolisian agar dapat terhindar dari proses hukum yang berlaku.

Kepolisian sebagai pelindung masyarakat berperan penting dalam mewujudkan keamanan dan kenyamanan dalam kehidupan masyarakat. Telah diketahui bahwa kejahatan aborsi merupakan kejahatan yang sangat meresahkan karna dapat membahayakan keselamatan jiwa dan merusak moral bangsa.

Berdasarkan hasil wawancara dengan Kanit PPA Polres Ternate, Fany F.A Syalahatu, menjelaskan bahwa meskipun kasus aborsi yang ditangani oleh pihak rumah sakit, penyidik tidak dapat langsung melakukan penyidikan, dikarenakan tindakan pasca aborsi kriminalis yang ditangani oleh pihak rumah sakit itu, tidak ada laporan langsung dari masyarakat maupun dari pihak rumah sakit yang menangani kasus tersebut.

Mengacu pada standar oprasional prosedur, dibagian unit PPA berdasarkan peraturan Kepala Kepolisian Negara Repoblik Indonesia Nomor. Polisi: 10 Tahun 2007, tentang organisasi dan tata kerja unit pelayanan perempuan dan anak (unit PPA) di lingkungan kepolisian Negara Repoblik Indonesia. Menurut ibu Fany Kanit PPA Polres Ternate, bahwa apabila terjadi kasus aborsi kriminalis dan dilaporkan kepada penyidik kepolisian secara otomatis penyidik harus langsung mengambil tindakan, Setelah ada laporan yang masuk pada pihak Kepolisian, laporan mulai diproses dan diolah, setelah itu pihak Kepolisian mulai melakukan penyidikan terhadap kasus atas tindak pidana tersebut, penyidikan yang dilakukan oleh pihak Kepolisian (khususnya oleh bagian reserse) akan dimulai dari saksi di tempat kejadian perkara (TKP), dan barang bukti yang ditemukan di tempat kejadian perkara. Setelah itu akan ditemukan suatu hal yang akan menjadi petunjuk dari kasus tersebut berdasarkan fakta dan laporan yang diterima oleh pihak Kepolisian.

Polisi di dalam melakukan suatu penyidikan kasus tindak aborsi yang sedang terjadi tersebut dibantu oleh saksi ahli yaitu dokter yang berwenang, dalam hal ini untuk membantu proses

13 Soerjono Soekanto dan Sri Mamudji, Poros Pengembangan Hukum Adat, ( Jakarta, Rajawali Pres., 2011)., hlm 14. 
visum barang bukti serta yang diduga sebagai tersangka, maka dibuatlah permintaan visum dengan pengantar visum oleh sentral pelayanan kepolisian terpadu (SPKT) setelah dibuat pengantar oleh SPKT, maka diberikanlah surat pengantar visum kerumah sakit untuk di visum.

Setelah di visum maka hasil visumnya tidak bisa diambil oleh petugas SPKT ataupun pihak lain yang bukan menangani kasus tersebut, yang dapat mengambil hanya pihak penyidik yang menanggani kasus tersebut. Apabila kasus tersebut adalah kasus aborsi kriminalis, maka hasil visum hanya dapat di ambil oleh penyidik wanita di unit PPA. ${ }^{14}$

Setelah mendapatkan visum dari si ibu atau wanita yang dicurigai maka pelaku dalam hal ini si ibu atau wanita tersebut harus menjalani proses penyidikan yang diantaranya adalah dipertanyakan siapa yang telah membantu dalam melakukan proses aborsi kriminalis atau penguguran kandungan secara paksa tersebut, apakah seorang dokter, bidan, dukun atau yang lainnya. Juga dipertanyakan siapa yang menyuruh, mengiming-imingi atau yang memprovokasi supaya si ibu melakukan tindakan aborsi atau pengguguran kandungan dan apakah tindakan aborsi atau pengguguran kandungan tersebut dilakukan secara terangterangan atau secara sembunyi-sembunyi.

Setelah semua keterangan pada proses penyidikan yang diperoleh dari si ibu dianggap sudah mencukupi maka berkas tersebut segera diproses dan selanjutnya dilimpahkan kepada Kejaksaan dan dari Kejaksaan jika dianggap cukup semua berkas tersebut maka pihak Kejaksaan langsung melimpahkan perkara tersebut kepada pihak Pengadilan.

Wawancara dengan Kanit Reskrim Polsek Pulau Ternate, Adam Ibrahim dan penyidik PPA Polsek Ternate Selatan Bripka. Riska Ismail, kedua-duanya mengatakan bahwa tidak ada penangganan kasus aborsi kriminalis sejak tahun 2016 sampai dengan $2018 .{ }^{15}$

Hasil wawancara dengan Kanit Reskrim Polsek Ternate Utara Agus Surya Darma. Penulis mendapatkan satu kasus penanganan kasus tindak pidana aborsi kriminalis yang telah di tangani oleh Polsek Ternate Utara pada tahun $2016 .^{16}$

Tabel 1

Data Penanganan Kasus Aborsi di Wilayah Polres Ternate Tahun 2016

\begin{tabular}{|c|c|c|c|c|c|}
\hline No & $\begin{array}{c}\text { Wilayah } \\
\text { Polres Ternate }\end{array}$ & Nama & Status & Kasus & Ket \\
\hline 1. & $\begin{array}{c}\text { Polsek Ternate } \\
\text { Utara }\end{array}$ & Rany Marsaoly & $\begin{array}{c}\text { Sudah } \\
\text { Menikah }\end{array}$ & $\begin{array}{c}\text { Aborsi } \\
\text { Kriminalis }\end{array}$ & Proses \\
\hline
\end{tabular}

Sumber: Polsek Ternate Utara (data yang telah diolah penulis).

Berdasarkan table 1 di atas, kasus aborsi kriminalis yang ditangani pihak kepilisian mulai dari tahun 2016 sampai dengan 2018 hanya satu kasus aborsi kriminalis yang ditangani oleh Polsek Ternate Utara. Hasil wawancara dengan Jaksa Friza Adi Yudha, di Kejaksaan Negeri Ternate, yang menanggani kasus tersebut mengatakan bahwa, surat pemberitahuan dimulainya penyidikan kasus tersebut pada bulan Agustus 2016 dan batas perkara dengan atas nama Rany Marsaoly, dilimpahkan ke kejaksaan pada bulan Februari 2017, namun karena berkas perkara dengan atas nama Rany Marsaoly dianggap oleh Jaksa belum lengkap pada tanggal 12 September 2017, sehingga dikembalikan lagi ke penyidik Polsek Ternate Utara dengan disertai beberapa petunjuk. Namun petunjuk yang dimaksud jaksa tidak dapat

\footnotetext{
${ }^{14}$ Hasil Wawancara dengan Kanit PPA Polres Ternate Ibu Fany F.A Syalahatu.Tanggal 14 Mei 2019

${ }^{15}$ Wawancara dengan Kanit Reskrim Polsek Pulau Ternate, Adam Ibrahim dan penyidik PPA Polsek Ternate Selatan Bripka. Riska Ismail.Tanggal 17 Mei 2019.

${ }^{16}$ Wawancara dengan Kanit Reskrim Polsek Ternate Utara Agus Surya Darma. Tanggal 17 Mei 2019
} 
diketahui oleh penulis, dengan alasan Jaksa hanya dapat menyampaikan langsung ke penyidik yang menanggani kasus tersebut. ${ }^{17}$

Wawancara dengan Direktur LSM Daurmala, Nurdewa Safar, mengatakan bahwa untuk kasus aborsi kriminalis yang pernah dilaporkan ke LSM Daurmala sejak tahun 2016 sampai 2018 hanya terdapat satu kasus di tahun 2016, yang menjadi pelapor adalah perempuan itu sendiri, karena dia tidak mau untuk melakukan aborsi namun atas paksaan pacarnya, ia terpaksa melakukan tindakan aborsi tersebut, tetapi yang bersangkutan tetap melaporkan ke LSM Daur Mala. Dalam kasus tersebut pacarnya adalah seorang prajurit TNI, maka LSM Daur Mala, menyerahkan kasus tersebut ke Polisi Militer yang langsung ditangani oleh penyidik militer. Peneliti menanyakan nama dan alamat, pelapor dan sebagai pelaku aborsi, kepada Direktur Daur Mala ibu Nurdewa Djafar namun, tidak mau mengatakan dengan alasan privasi dari si pelapor dan juga pelaku aborsi. ${ }^{18}$

Tabel 2

Jumlah Kasus Pasca Aborsi Medicalis dan Pasca Aborsi Kriminalis Yang Pernah Ditangani RSUD Chasan Boesorie Ternate

Tahun 2016-2018

\begin{tabular}{|c|c|c|c|c|c|c|c|}
\hline No & Nama & Tgl/Bulan/Tahun & Usia & Status & Alamat & $\begin{array}{c}\text { Tindakan } \\
\text { Medis }\end{array}$ & Ket \\
\hline 1. & $\begin{array}{c}\text { Siti } \\
\text { Nuryati }\end{array}$ & 19 Januari 2016 & $\begin{array}{c}21 \\
\text { Tahun }\end{array}$ & Menikah & Akehuda & $\begin{array}{c}\text { Pasca } \\
\text { Aborsi } \\
\text { Medicalis }\end{array}$ & \\
\hline 2. & Cristi & 01 April 2016 & $\begin{array}{c}28 \\
\text { Tahun }\end{array}$ & Menikah & Ngidi & $\begin{array}{c}\text { Pasca } \\
\text { Aborsi } \\
\text { Medicalis }\end{array}$ & \\
\hline 3. & Ines & 15 Juli 2016 & $\begin{array}{c}16 \\
\text { Tahun }\end{array}$ & Belum & $\begin{array}{l}\text { Kompleks } \\
\text { Pohon Pala }\end{array}$ & $\begin{array}{c}\text { Pasca } \\
\text { Aborsi } \\
\text { Kriminalis } \\
\end{array}$ & \\
\hline 4. & Nurmina & 26 Juli 2016 & $\begin{array}{c}24 \\
\text { Tahun }\end{array}$ & Menikah & Jati & $\begin{array}{c}\text { Pasca } \\
\text { Aborsi } \\
\text { Medicalis }\end{array}$ & \\
\hline 5. & Masita & 27 Juli 2016 & $\begin{array}{c}21 \\
\text { Tahun }\end{array}$ & Menikah & Tabam & $\begin{array}{c}\text { Pasca } \\
\text { Aborsi } \\
\text { Medicalis }\end{array}$ & \\
\hline 6. & $\begin{array}{l}\text { Dewi } \\
\text { Nifu }\end{array}$ & 16 Februari 2017 & $\begin{array}{c}34 \\
\text { Tahun }\end{array}$ & Menikah & Lelong & $\begin{array}{c}\text { Pasca } \\
\text { Aborsi } \\
\text { Medikalis }\end{array}$ & \\
\hline 7. & Irma & 01 April 2017 & $\begin{array}{c}22 \\
\text { Tahun }\end{array}$ & Menikah & Dufa-Dufa & $\begin{array}{c}\text { Pasca } \\
\text { Aborsi } \\
\text { Kriminalis } \\
\end{array}$ & \\
\hline 8. & $\begin{array}{c}\text { Siti } \\
\text { Nurbaya }\end{array}$ & 03 April 2017 & $\begin{array}{c}22 \\
\text { Tahun }\end{array}$ & Menikah & Sasa & $\begin{array}{c}\text { Pasca } \\
\text { Aborsi } \\
\text { Medicalis }\end{array}$ & \\
\hline
\end{tabular}

\footnotetext{
${ }^{17}$ Hasil Wawancara dengan Jaksa Friza Adi Yudha, di Kejari Ternate. 22 Mei 2019.

${ }^{18}$ Hasil Wawancara dengan Direktur LSM Daur Mala, Nurdewa Djafar, 30 Desember 2017.
} 
de Jure; Jurnal Ilmiah Ilmu Hukum $\bigcirc$ Vol. 1 No. 1 Desember (2019) : 1-15

\begin{tabular}{|c|c|c|c|c|c|c|}
\hline 9. & $\begin{array}{c}\text { Sita } \\
\text { Herlina }\end{array}$ & 10 Agustus 2017 & $\begin{array}{c}23 \\
\text { Tahun }\end{array}$ & Belum & Ngade & $\begin{array}{c}\text { Pasca } \\
\text { Aborsi } \\
\text { Kriminalis } \\
\end{array}$ \\
\hline 10. & Murni Ati & 13 Agustus 2017 & $\begin{array}{c}34 \\
\text { Tahun }\end{array}$ & Menikah & Toloko & $\begin{array}{c}\text { Pasca } \\
\text { Aborsi } \\
\text { Medicalis }\end{array}$ \\
\hline 11. & $\begin{array}{c}\text { Intan } \\
\text { Ahmad }\end{array}$ & 25 Februari 2018 & $\begin{array}{c}18 \\
\text { Tahun }\end{array}$ & Belum & Kalumata & $\begin{array}{c}\text { Pasca } \\
\text { Aborsi } \\
\text { Kriminalis } \\
\end{array}$ \\
\hline 12. & Siti & 2 Mei 2018 & 20 & Belum & Marikrubu & $\begin{array}{c}\text { Pasca } \\
\text { Aborsi } \\
\text { Kriminalis }\end{array}$ \\
\hline 13. & Hartini & 30 Mei 2018 & 36 & Menikah & Gambesi & $\begin{array}{c}\text { Pasca } \\
\text { Aborsi } \\
\text { Medicalis }\end{array}$ \\
\hline 14. & $\begin{array}{c}\text { Sri } \\
\text { Rahayu }\end{array}$ & 12 Juni 2018 & 19 & Belum & Akehuda & $\begin{array}{c}\text { Pasca } \\
\text { Aborsi } \\
\text { Kriminalis } \\
\end{array}$ \\
\hline 15. & Novita & 23 Juni 2018 & 18 & Belum & Kalumata & $\begin{array}{c}\text { Pasca } \\
\text { Aborsi } \\
\text { Kriminalis }\end{array}$ \\
\hline 16. & $\begin{array}{c}\text { Siti } \\
\text { Masita }\end{array}$ & 17 Agustus 2018 & 30 & Menikah & Bastiong & $\begin{array}{c}\text { Pasca } \\
\text { Aborsi } \\
\text { Medicalis }\end{array}$ \\
\hline 17. & Fatriana & $\begin{array}{l}23 \text { Agustus } \\
20018\end{array}$ & 26 & Menikah & Maliaro & $\begin{array}{c}\text { Pasca } \\
\text { Aborsi } \\
\text { Medicalis } \\
\end{array}$ \\
\hline 18. & Husni & 1 Oktober 2018 & 19 & Belum & Ngade & $\begin{array}{c}\text { Pasca } \\
\text { Aborsi } \\
\text { Kriminalis } \\
\end{array}$ \\
\hline 19. & Nurmila & $\begin{array}{c}8 \text { November } \\
2018\end{array}$ & 32 & Menikah & Kalumpang & $\begin{array}{c}\text { Pasca } \\
\text { Aborsi } \\
\text { Medicalis }\end{array}$ \\
\hline 20. & Sumarti & $\begin{array}{c}12 \text { November } \\
2018\end{array}$ & 21 & Belum & Jambula & $\begin{array}{c}\text { Pasca } \\
\text { Aborsi } \\
\text { Kriminalis }\end{array}$ \\
\hline
\end{tabular}

Sumber: Rumah Sakit Umum Daerah Chasan Boesorie Ternate (data yang telah diolah penulis).

Hasil tabel 2 di atas, berdasarkan data dari pihak RSUD Chasan Bosoerie Ternate, di ruangan bagian ginekologi yang khususnya menanggani penyakit pasien yang berhubungan dengan wanita yaitu pendarahan, aborsi atau pengguguran kandungan, dari data tersebut terdapat 20 kasus pasca aborsi medicalis dan pasca aborsi kriminalis, yang telah ditangani oleh pihak medis di RSUD Cahsan Bosoerie Ternate, 12 orang berstatus menikah, dan 8 orang diantaranya belum menikah. 
Hasil dari data aborsi 20 kasus terdapat 9 kasus Aborsi Kriminalis yang dilakukan pertolongan oleh pihak ruma sakit setelah pasca aborsi yang dilakukan oleh pelaku dengan cara meminum obat kimia dan ramuan herbal penguguran kandungan, sedangkan 11 kasus aborsi medicalis dilakukan tindakan medis untuk melakukan aborsi dikarenakan pasien tersebut mengalami gangguan pada kehamilan dengan berbagai faktor penyakit yang diderita pasien tersebut sehingga pihak medis dengan mengambil tindakan penyelamatan kepada pasien, atas persetujuan dokter untuk mengambil tindakan aborsi medicalis.

Wawancara dengan Nona Ines status belum menikah, umur 19 tahun beralamat di Kelurahan Kompleks Pohon Pala, melakukan tindakan aborsi pada tahun 2016, dengan massa kehamilan 1 Bulan, pelaku mengatakan bahwa bukan keinginan pacar yang menyuruh untuk melakukan tindakan aborsi, awalnya tidak ada keinginan sendiri untuk melakukan tindakan aborsi, namun dikarenakan tekanan rasa takut terhadap orang tua dan suami, namun karena mendapatkan dorongan dari pihak keluarga sehingga pelaku dapat memberanikan diri agar kehamilannya dapat digugurkan dengan cara meminum obat-obatan yang diberikan oleh seorang bidan atas permintaan yang bersangkutan, tujuan tindakan yang pelaku lakukan agar tidak diketahui oleh kedua orang tua.

Pelaku meminta bantuan dari seorang bidan yang bertugas di salah satu Rumah Sakit di Kota Ternate, untuk melakukan aborsi kepada Nona Ines, setelah satu minggu terjadi pendarahan sehingga dilarikan ke rumah sakit umum Chasan Bosoerie untuk meminta bantuan tenaga medis memberikan pertolongan, setelah terjadi aborsi provokatus kiminalis atau pasca aborsi kriminalis. ${ }^{19}$

Wawancara dengan Ny. Irma status sudah menikah, umur 24 tahun beralamat di Kelurahan Dufa-Dufa, melakukan tindakan aborsi kriminalis pada tahun 2017, dengan masa kehamilan 1 Bulan, bahwa terjadi kehamilan karena terjadi hubungan biologis dalam perselingkuhan, ia mengatakan bahwa awalnya tidak ada keinginan sendiri untuk melakukan tindakan aborsi, namun dikarenakan tekanan rasa takut terhadap suami dan orang tua, dan mendapatkan paksaan dari pacar sehingga ia dapat memberanikan diri agar kehamilannya dapat digugurkan dengan meminta bantuan dari pihak medis disalah satu rumah sakit di Kota Ternate, dengan diberikan obat penguguran kandungan, selama satu minggu berada di rumah sakit terjadihlah penguguran kandungan atau aborsi. Tujuan tindakan yang ia lakukan agar tidak diketahui oleh suami maupun kedua orang tua. Namun akhirnya ketahuan lantaran karena pengguran kandungan yang pelaku lakukan sudah membahayakan dirinya, sehingga pelaku pengguguran kandungan dilarikan kerumah sakit dan akhirnya di ketahui oleh orang tua. ${ }^{20}$

Wawancara dengan Nona Sita Herlina status belum menikah, umur 23 tahun beralamat di Kelurahan Gade, melakukan tindakan aborsi provokatus kiminalis pada tahun 2017, dengan masa kehamilan 2 Bulan, ia mengatakan bahwa bukan keinginan diri sendiri, tetapi pacar dan pihak keluarga yang mendorong untuk melakukan tindakan aborsi, sehingga ia dapat memberanikan diri agar kehamilannya dapat digugurkan dengan meminta bantuan dari pihak medis disalah satu rumah sakit di Kota Ternate, dengan diberikan obat penguguran kandungan, selama satu minggu baruhlah terjadi pendarahan kemudian dilakukanlah tindakan penguguran kandungan atau aborsi di rumah sakit tersebut. Tujuan tindakan yang ia lakukan dikarenakan pacarnya belum siap dari sisi ekonomi dan menghadapi kenyataan untuk berkeluarga, sekaligus rasa takut kepada keluarganya sehingga ia menyuruh melakukan tindakan aborsi. ${ }^{21}$

Selain kasus aborsi yang dijelaskan di atas, terdapat 1 kasus borsi yang dilakukan oleh dukun beranak di tahun 2017 bulan agustus . Hasil wawancara dengan bidan Saida Talib,

\footnotetext{
${ }^{19}$ Hasil wawancara dengan Nona Ines, Tanggal 28 Mei 2019.

20 Wawancara dengan Ny. Irma. Tanggal 28 Mei 2019.

21 Wawancara dengan Nona Sita Herlina Tanggal 29 Mei 2019.
} 
menjelaskan bahwa Ibu Murni Ati umur 34 tahun status telah menikah, beralamat di kelurahan Toloko. Ibu Murni Ati melakukan aborsi, dengan memasukan benda tumpul (kayu) yang panjang $12 \mathrm{~cm}$. Pada saat penanganan medis yang dilakukan oleh bidan, saat memasukan obat perangsang kedalam vagina, untuk dapat mengeluarkan janin yang telah keguguran, barulah bidan mengetahui bahwa ada terdapat benda tumpul (kayu) di dalam rahim Ibu Murni Ati, yang telah disengaja memasukan benda tersebut, setelah ditemukan benda tumpul (kayu) tersebut lalu dikeluarkan dan di obati oleh bidan yang bertugas di ruangan kebidanan Ginekologi di RSUD Chasan Bosoeri Ternate. ${ }^{22}$

Wawancara dengan Nona Intan Ahmad status belum menikah, umur 18 tahun beralamat di Kelurahan Kalumata, melakukan tindakan aborsi kriminalis pada tahun 2018, dengan masa kehamilan 2 Bulan, ia mengatakan bahwa ada keinginan sendiri walaupun ada rasa takut, tetapi pacar dan pihak keluarga yang menyuruh melakukan tindakan aborsi, sehingga ia dapat memberanikan diri agar kehamilannya dapat digugurkan dengan meminta bantuan dari bidan yang bertugas di salah satu Klinik Bersalin di Kota Ternate, dengan diberikan tindakan seperti pijatan keras di perut dan obat untuk melakukan penguguran kandungan atau aborsi, dan selama lima hari baruhlah terjadi pendarahan kemudian dilakukanlah tindakan penguguran kandungan atau aborsi di klinik bersalin tersebut. Namun dari pihak klinik bersalin tidak mampu menangani, karena terjadi pendarahan terus-menerus sehingga dirujuk ke rumah sakit umum Chasan Bosoerie untuk diberikan pertolongan. Tujuan tindakan yang ia lakukan alasannya karena belum siap untuk menikah. ${ }^{23}$

Hasil wawancara dengan Kepala Ruangan Ginekologi Ibu Kartini Kalbamay, mengatakan bahwa rata-rata pelaku tindakan aborsi melakukan tindakannya dengan cara meminum obat Kimia untuk penguguran kandungan, jamu tradisional yang sengaja diramu untuk penguguran kandungan, dan mengunakan benda tumpul seperti kayu dengan cara memasukan lewat vagina sampai kerahim, hingga terjadi pendarahan dan mengalami keguguran. ${ }^{24}$ Jumlah 23 kasus pasca aborsi dan 4 kasus aborsi dengan total jumlah data medis 27 kasus.

\section{B. Faktor Yang Menjadi Kendala Penyidik Kepolisian Dalam Mengungkap Kasus Tindak Pidana Aborsi Di Kota Ternate.}

Hasil wawancara dengan Fany F.A Syalahatu,.selaku Kanit PPA Polres Ternate, menjelaskan ada beberapa faktor yang menjadi kendala yang dialami oleh penyidik kepolisian dalam mengungkap kasus tindak pidana aborsi, yaitu tidak adanya standar oprasional prosedur atau kerja sama yang dibuat antara pihak kepolisian dengan pihak rumah sakit dalam penangganan khususnya kasus aborsi yang terjadi di rumah sakit, sehingga penyidik kepolisian dalam mencari kasus aborsi baik yang dilakukan oleh pihak rumah sakit, maupun pelaku aborsi yang dibawah kerumah sakit untuk mendapatkan pertolongan medispun, penyidik tidak mendapatkan informasi dan data sehingga penyidik kepolisian tidak dapat menggungkap kasus aborsi tersebut.

Tidak ada upaya penyidik kepolisian dalam menanggani kasus tindak pidana aborsi yang dilakukan oleh pihak medis maupun penangganan pasca aborsi yang ditangani oleh pihak rumah sakit. Dikarenakan tidak adanya laporan dari pihak rumah sakit dan dari masyarakat, sehingga menyulitkan penyidik dalam mengambil langkah melakukan penyidikan, di rumah sakit kemudian tidak ada laporan dari rumah sakit, maupun petugas kepolisian yang datang setiap saat untuk menanyakan perkembagan penangganan medis terkait pengguguran kandungan atau kita kenal dengan istilah aborsi.

\footnotetext{
${ }^{22}$ Hasil wawancara dengan Bidan Saida Talib di RSUD Chasan Bosoeri Ternate, Tanggal 29 Mei 2019.

${ }^{23}$ Wawancara dengan Sinta Apriani. Tanggal 28 Mei 2019.

${ }^{24}$ Hasil wawancara dengan Kepala Ruangan Ginekologi Ibu Kartini Kalbamay, di RSUD Chasan Bosoeri Ternate, Tanggal 29 Mei 2019.
} 
Kendala selanjutnya yaitu dari masyarakat itu sendiri, kurangnya pengetahuan tentang pergaulan bebas tersebut yang akhirnya sering terjadi hubungan sex diluar nikah yang akhirnya membuahkan sesuatu yang tidak diinginkan. Masyarakat yang menganggap bahwa hal tersebut adalah sebagai aib keluarga yang harus ditutupi, sehingga tak segan keluarga berani untuk menyuruh melakukan tindakan abortus begitupun dengan yang bersangkutan yang berani melakukan karena desakan dari keluarga, pacar bahkan teman atau sahabat.

Keadaan seperti ini mereka rela rnengeluarkan uang berjuta-juta rupiah bagi para pelaku aborsi untuk membayar dokter atau tenaga medis maupun dukun beranak untuk bersedia melakukan tindakan pengguguran kandungan. Dan bagi banyak masyarakat tindakan ini adalah tindakan yang paling benar untuk menutupi sebuah aib keluarga. Padahal dari tindakan tersebut tidak sedikit yang harus kehilangan nyawa atau sedikitnya mereka mengalami keadaan dimana rahim mereka rusak dan tidak akan dapat lagi memiliki anak. Kesadaran rnasyarakat yang amat sangat diperlukan dalam menuntaskan masalah ini. Disamping itu karena kasus ini bukan merupakan kasus delik aduan maka agak sulit untuk menuntaskan kasus ini hingga keakarnya, karena mereka yang tahu dengan masalah ini enggan untuk melaporkannya kepada pihak yang berwajib. ${ }^{25}$

Wawancara dengan Kanit Reskrim Polsek Ternate Utara Agus Surya Darma. Mengatakan bahwa, kendala dalam penyidikan untuk mencari barang bukti untuk mengungkap kasus tindak pidana aborsi, adalah pihak kepolisian sering sekali sulit mengidentifikasi hasil dari barang bukti abortus, karena hasil-hasil dari perbuatan tersebut sering ditemukan bukti yang sudah hancur atau dibuang entah kemana.

Kendala selanjutnya adalah saksi yang tidak mau memberikan keterangan. karena kasus ini bukan merupakan kasus delik aduan maka agak sulit untuk menuntaskan kasus ini hingga keakarnya, karena mereka yang mengetahui masalah ini enggan untuk melaporkannya kepada pihak yang berwajib. Kegagalan aparat penegak hukum untuk mengungkap berbagai kasus, hanya karena keengganan saksi untuk memberikan informasi kepada mereka atau saksi tidak mau menampakkan diri agar tidak memberikan kesaksian karena takut diancam oleh pelaku tindak pidana.

Para pelaku biasanya memiliki kekuatan untuk menekan ataupun mengintimidasi saksi. Biasanya dalam kasus aborsi ini saksi adalah orang terdekat tersangka misalnya keluarga atau teman dekat tersangka yang melakukan aborsi. Saksi merasa malu maupun kasihan kepada tersangka sehingga saksi bungkam, tidak mau memberikan keterangan ataupun sama sekali tidak mau dirinya diketahui. ${ }^{26}$

Kanit Reskrim Polsek Pulau Ternate, Adam Ibrahim, mengatakan bahwa ada beberapa kendala penyidik untuk mengungkap kasus tindak pidana aborsi yaitu :

a. tidak adanya saksi

b. kurangnya barang bukti

c. tidak adanya laporan dari masyarakat.

d. tidak ada laporan dari rumah sakit.

Sulitnya pihak kepolisian, dalam mencari informasi serta mengumpulkan data tersangka yang berhubungan dengan kasus tindak pidana aborsi, karena aborsi merupakan aib bagi seorang wanita, yang berarti jika memberikan informasi berarti membuka aib mereka sendiri. Bahkan pelaku yang sudah didugapun sulit untuk ditemukan, berpindah tempat tinggal ataupun kota dipilih untuk sekedar menghilangkan jejak sehingga polisi kesulitan untuk menelusuri pelakunya.

${ }^{25}$ Hasil wawancara dengan Fany F.A Syalahatu,.selaku Kanit PPA Polres Ternate. Tanggal 18 Juni

${ }^{26}$ Wawancara dengan Kanit Reskrim Polsek Ternate Utara Agus Surya Darma. Tanggal 23 Mei 2019. 
Kendala yang sering dihadapi adalah menentukan tersangka yang melakukan tindak pidana tersebut. Sulitnya menentukan tersangka didalam proses penyelidikan dikarenakan kurangnya barang bukti yang ditemukan di lokasi kejadian, tidak adanya jejak yang di tinggalkan oleh pelaku dan lain sebagainya.

Pihak penyidik harus jeli dan cermat untuk dapat menemukan tersangka pelaku tindak pidana. Taktik penyidikan harus dilakukan agar pelaku sebenarnya dapat diungkap dan tidak terjadi salah tangkap yang akan merugikan di kemudian hari baik bagi tersangka maupun penyidik. ${ }^{27}$

Kendala-kendala yang ada selama proses penyelidikan dan penyidikan tentunya harus dapat mencari solusi yang terbaik agar suatu tindak pidana aborsi tersebut dapat terungkap dengan jelas dan dapat menemukan kebenaran yang materiil yaitu kebenaran yang sebenar-benarnya yang didapat dari fakta-fakta yang ditemui dilapangan bukan hanya sebatas kebenaran formil yang belum tentu dapat dijamin kebenarannya.

Dengan dilakukannya berbagai upaya yang dilakukan oleh pihak penyidik diharapkan esensi dari tujuan hukum pidana yaitu mencari kebenaran materiil dapat dilaksanakan. Hal ini dimaksudkan untuk menghindari adanya kekeliruan dalam penjatuhan pidana terhadap diri seseorang.

\section{PENUTUP}

Berdasarkan uraian pembahasan di atas maka kesimpulan penulis adalah rata-rata motif pelaku melakukan tindakan aborsi kriminalis karena adanya paksaan dari pacar, rasa takut terhadap orang tua, suami, dan dorongan dari pihak keluarga, sehingga pelaku memberanikan diri untuk melakukan tidakan aborsi. Begitu pula dengan Penyidik Kepolisian di Polres maupun Polsek-Polsek yang belum maksimal dalam menggungkap kasus tindak pidana aborsi diwilayah Kota Ternate. Kendala penyidik kepolisian dalam mengungkap kasus tindak pidana aborsi karena tidak adanya saksi, barang bukti, laporan dari masyarakat dan tidak adanya laporan dari rumah sakit apabila ada terdapat kasus aborsi yang di tangani pihak rumah sakit. Sehingga masih maraknya pelaku tindak pidana aborsi yang terjadi di Kota Ternate.

\section{DAFTAR PUSTAKA}

Abdul Bari Saifuddin. Pelayanan Kesehatan Maternal Dan Neonatal. Yayasan Bina Pustaka Sarwono Prawirohardjo Jakarta, 2002.

Ari Yunanto, Hukum Pidana Malpraktik Medik Tinjauan dan Perspektif Medikolegal. Penerbit Andi, Yogyakarta. 2010.

Djisman Samosir, Segenggam Tentang Hukum Acara Pidana, Penerbit Nusa Aulia, 2013.

Estu Tiar. Edisi 2 Modul Kebidanan Manajemen Aborsi Inkomplet. Jakarta, Penerbit Buku Kedokteran EGC, 2009.

Masrudi Muchtar, Etika Profesi Hukum Kesehatan Perspektif Profesi Bidan Dalam Pelayanan Kebidanan Di Indonesia. Yogyakarta Pustaka Baru Press. 2016.

Peter Mahmud Marzuki, Penelitian Hukum, Jakarta, Kencana., 2007.

Soerjono Soekanto dan Sri Mamudji, Poros Pengembangan Hukum Adat, Jakarta, Rajawali Pres. 2011.

\section{Internetan.}

http://digilib.unila.ac.id/2827/12/BAB\%20II.pdf.di Kutip Dellyana,Shant.1988,Konsep Penegakan Hukum. Yogyakarta.

\footnotetext{
${ }^{27}$ Wawancara dengan Kanit Reskrim Polsek Pulau Ternate, Adam Ibrahim Tanggal 14 Mei 2019.
} 
http://sonny-tobelo.blogspot.co.id/2009/02/peranan-polri-dalam-penyidikan-tindak.html https://ningrumwahyuni.wordpress.com/2009/11/22/abortus-dalam-kaitannya-dengan-ilmukedokteran-forensik-dan-medikolegal.

https://www.kompasiana.com/janewinarni/pengambilan-keputusan-etis-tentang-kasusabortus-dalam-medis-hukum-dan-agama

http://komunikasi.trunojoyo.ac.id/wp-content/Motif-Pelaku-Aborsi.pdf

\section{Peraturan Perundang-Undangan}

Peraturan Kepala Kepolisian Negara Repoblik Indonesia Nomor 14 Tahun 2012 Tentang Menajement Penyidikan Tindak Pidana.

Undang-Undang Nomor 2 Tahun 2002 Tentang Kepolisian Negara Republik Indonesia. Fokusmedia. 2012. 